\title{
Low night temperatures during the early growth phase enhance flowering in primocane shoots of red raspberries (Rubus idaeus L.)
}

\author{
E. Contreras ${ }^{\mathrm{a}}$, J. Grez ${ }^{\mathrm{a}}$, S. Sánchez ${ }^{\mathrm{a}}$, J.A. Alcalde ${ }^{\mathrm{a}}$, D Neri ${ }^{\mathrm{b}}$ and M. Gambardella ${ }^{\mathrm{a}, *}$ \\ ${ }^{a}$ Departamento de Fruticultura y Enología, Facultad de Agronomía e Ingeniería Forestal, \\ Pontificia Universidad Católica de Chile. Avenida Vicuña Mackenna 4860, Macul, Santiago, Chile \\ ${ }^{\mathrm{b}}$ Dipartimento di Scienze Agrarie, Alimentari e Ambientali, Universitá Politecnica delle Marche. \\ Via Brecce Bianche, 60131 Ancona, Italy
}

Received 18 January 2019; accepted 8 May 2019

\begin{abstract}
.
BACKGROUND: In red raspberries, two fruiting traits are distinguished, and classified as primocane and floricane fruiting. Primocane cultivars represent greater economic relevance; they are adapted to warm climate zones and have an elongated production period. However, this classification can be complicated since fruiting is affected by both environmental and genetic factors. In 'Heritage', the main cultivar used in Chile, flowering is inhibited in shoots produced the first season when grown in temperate zones with low thermal oscillation.

OBJECTIVE: This study evaluated the effect of cold temperature during shoot growth on fruiting parameters in different genotypes.

METHODS: Plants of the cultivars 'Autumn Bliss', 'Heritage', 'Meeker' and 'Tulameen' were tested at low night temperatures. We evaluated these growing characteristics for each cultivar; days until to first visible floral button, number of floral laterals and meristematic bud differentiation. We also analysed the variations associated with expression of the gene RiTFL1, on flowering inhibition.

RESULTS: There is an effect of temperature on flowering, growth and RiTFL1 expression, mainly in cvs. 'Heritage' and 'Meeker'. Flowering was enhanced in 'Heritage', while 'Meeker' exhibited an intermediate behaviour, since seasonal shoots managed to flower with a 60-night cold treatment. In both cultivars, growth was reduced, and RiTFL1 was repressed in cold treated plants.

CONCLUSIONS: Genotypes with intermediate behaviour require low temperatures for floral induction, which could be associated with RiTFL1 gene repression with low-temperature treatments.
\end{abstract}

Keywords: Induction, vernalisation, primocane, floricane, flowering, raspberry, low temperature

\footnotetext{
${ }^{*}$ Corresponding author. M. Gambardella, Departamento de Fruticultura y Enología, Facultad de Agronomía e Ingeniería Forestal, Pontificia Universidad Católica de Chile. Avenida Vicuña Mackenna 4860, Macul, Santiago, Chile. Tel.: +56223544113; E-mail: mgambardella@uc.cl.
} 


\section{Introduction}

In red raspberries (Rubus idaeus L.), two cultivar groups can be distinguished by their flowering and fruiting behavior. Floricanes only flower on second-year lignified shoots and therefore present summer production. Primocanes can flower on either lignified or seasonal shoots, resulting in both summer and autumn fruit production [1].

Primocane cultivars have increasing economic importance because they may flower and produce fruit twice per season, enabling extended harvest periods, increased profits and greater adaptation to temperate climates [2]. Primocane cultivars have also allowed off-season fruit production and expanded cultivation areas $[1,3]$. However, flowering in seasonal shoots (primocane) is a poorly studied trait, and breeders often find it difficult to evaluate. A segregated population has shown gradual expression in this trait, and some genotypes show reduced fructification in the shoot tip, while others may have fruits only in the upper part section of the seasonal shoot, thus indicating high primocane-fruiting strength genotypes [4].

'Heritage' was one of the first cultivar defined as primocane. This was obtained via genetic improvements, and the cv. was released in North America in 1969 [5]. 'Heritage' has been widely cultivated in several countries because of its strong, and it is the most important cultivar in Chile to date [6]. Despite its primocane fruiting trait, 'Heritage' has shown higher fruiting prevalence in primocane and in climates with marked day-night temperature oscillations. However, when taken to temperate zones with maritime influence, fruiting in seasonal stems can be minimal and even non-existent [4].

Several studies have been conducted to evaluate the physiological aspects that determine different raspberry fruiting traits and the influence of the environmental factors involved. Primocane and floricane fruiting behaviour, although being genotypic traits $[7,8]$, have shown marked environmental influences mainly determined by the interaction of temperature and photoperiod $[1,9,10]$.

In floricane cultivars flower initiation is controlled by the interaction of short photoperiods and low temperature $[1,9]$. Trials conducted with cv. 'Glen Ample' was subjected to different temperature treatments showed that temperature at $18^{\circ} \mathrm{C}$, or above, inhibited floral induction despite being under short photoperiodic conditions. However, at temperatures below $15^{\circ} \mathrm{C}$, floral induction occurred regardless of photoperiod $[9,11]$.

In primocane cultivars, temperature and photoperiod are less influential for floral induction, which can occur at higher temperatures and longer photoperiods. However, flowering can be stimulated in some cultivars by subjecting the plants to low temperatures during the growth period [12,13].

Vernalisation, the process by which low temperatures favour inception of the reproductive stage [14], is an adaptation mechanism to temperate climates in some species which require a cold period during plant development before being receptive to another signal for floral induction $[15,16]$. In the cultivar 'Heritage', the need for vernalisation in seasonal shoots may explain the differences in fruiting traits in different climatic environments. Under temperate climate conditions of maritime influence (average temperatures of $20^{\circ} \mathrm{C}$ in the summer and $7^{\circ} \mathrm{C}$ in the winter), flowering is scarce and is concentrated in the upper part of the shoot, while in areas with a marked thermal amplitude (premontane zones), flowering extends to the long on primocane shoots in a higher number of buds from the apex to down. Therefore, 'Heritage' has been classified as slightly primocane-fruiting, while other recently released cultivars classified as highly primocane-fruiting are insensitive to this type of stimulus [4].

Induction and flower development have been widely studied in model species such as Arabidopsis thaliana, Hordeum vulgare and Triticum aestivum, and have shown that the flowering process is activated by both internal and external plant stimuli. Gibberellin and the plant's age are internal control factors, while photoperiod and vernalisation are environmental stimuli that trigger the flowering process [17].

Molecularly, this process involves a complex network of highly specific genes, associated with different metabolic pathways [18]. The genes, SUPPRESSOR OF CONSTANS 1 (SOC1), APETALA 1 (AP1) and LEAFY (LFY), are among the most critical genetic processes that must be activated to identify the floral meristem $[19,20]$. 
The leaves receive the photoperiod signal, where light stimulates genic expression of FLOWERING LOCUS T (FT), a signal that is transferred to the meristematic apex stimulating the gene, SOC1, which is the main flowering gene [19]. In Arabidopsis, flowering is induced by cold treatments by epigenetic silencing of FLOWERING LOCUS C (FLC) [21]. In this species, prolonged cold treatments can reverse late flowering [20]. This response to vernalisation has revealed specific repressor genes for each species, which can be inactivated with periods of cold exposure, thus inducing flowering [15].

Although no detailed descriptions are available for the genes involved in raspberries, reviewing what happens in other species of the Rosaceae family with similar reproductive behaviour is of interest. In Fragaria vesca, flowering is induced by short days and low temperature during the autumn and after a period of winter recess, the flowers emerge in the spring [22]. Cultivars with such trait are called short-day cultivars, and in raspberries, floricane cultivars exhibit similar behaviour. Some strawberry cultivars, called day-neutral cultivars, feature continuous flowering, where the repressor gene, TERMINAL FLOWER 1, is inactive [23]. This gene, which is regulated by temperature and photoperiod, is the major flowering repressor in Rosaceae, similar to the FLC, VRN2 and BvFT1 genes in Arabidopsis, wheat and beets, respectively. In Fragaria vesca, FvTFL1 is repressed at low temperatures and short days. However, in long days with temperatures below $13^{\circ} \mathrm{C}, F v \mathrm{TFL} 1$ expression is also suppressed, regardless of photoperiod [24], while at temperatures above $20^{\circ} \mathrm{C}$, flowering is inhibited because FvTFL1 mRNA is increased [16].

This study evaluated the effect of cold temperature treatments at night on floral induction and bud differentiation in four raspberry cultivars. Additionally, RiTFL1 gene expression was evaluated in the plants subjected to cold to determine whether RiTFL1 is involved in the vernalisation and whether the differences in expression are related to the degree of the primocane-fruiting trait in raspberry genotypes. In the trials, we used the moderate primocane-fruiting cultivar 'Autumn Bliss', the weak primocane-fruiting cultivar 'Heritage' [4], and the floricane cultivars 'Meeker' and 'Tulameen'.

\section{Materials and methods}

\subsection{Plant material and experimental design}

The plants were propagated from etiolated buds, obtained from roots, which were stored in a cold chamber at $2{ }^{\circ} \mathrm{C}$ for three weeks, of the cultivars 'Autumn Bliss', 'Heritage', 'Meeker' and 'Tulameen', were grown under out-door conditions, at the Catholic University of Chile, in Santiago ( $33^{\circ} 27^{\prime} \mathrm{S}, 70^{\circ} 38^{\prime} \mathrm{W}$ ), placed in 6.5-litre pots, using a substrate of coconut fibre and peat (70:30 by vol.), fertilised with 1'g Basacote/plant (6 months) slow release-fertiliser $(15 \%$ N, $8 \%$ P, 12\% K plus micronutrients, Compo Expert, Germany). Fertiliser was applied weekly via irrigation for four months, using 1 'g/plant/week of Ultrasol fast-acting fertiliser $(25 \% \mathrm{~N}, 10 \% \mathrm{P}, 10 \%$ K; SQM, Chile).

The plants were established at the beginning of November in two seasons. When the plants reached a height of 50 ' $\mathrm{cm}$ (on December 15), night-time cold treatments were conducted during the dark hours (approximately 9 hours per the seasonal photoperiod). The plants were transferred to cold chambers at $2^{\circ} \mathrm{C}$ every day at dusk, maintaining the same hours of light as under natural ambient condition. The treatment was applied for $0,15,30$ and 60 nights. For the floricane cultivars, the 60-night treatment was only conducted during the second season of evaluation. Details of the temperature regimes for the different treatments are given in Table 1, Table 2 and Fig. 1.

The following flowering parameters were evaluated weekly: Number of days to the first visible flower bud, number of floral laterals, number of flowers per plant, shoot height and total number of nodes. During the second year of the trial, at the end of April before the winter recess, the differentiation state was also evaluated by meristematic analysis of the undeveloped buds. This analysis was performed under a magnifying glass at $63 \times$ (increase), using the methodology of [25], which scores the morphological changes in the meristem during floral development on a scale from 0 to 8 . 
Table 1

Temperatures recorded during the red raspberry trial evaluation period in Santiago, Chile.

\begin{tabular}{|c|c|c|c|c|c|c|c|c|}
\hline \multirow[t]{2}{*}{ Temperature } & \multirow[t]{2}{*}{ Nov } & \multicolumn{2}{|c|}{ Dec } & \multicolumn{2}{|c|}{ Jan } & \multirow[t]{2}{*}{ Feb } & \multirow[t]{2}{*}{ Mar } & \multirow[t]{2}{*}{ Apr } \\
\hline & & Control & Treatment & Control & Treatment & & & \\
\hline Min. & 14.1 & 13.8 & 8.2 & 20.1 & 16.1 & 17.8 & 18.1 & 10.9 \\
\hline Max. & 23.6 & 24.7 & 24.7 & 26.2 & 25.5 & 26.4 & 24.9 & 17.3 \\
\hline Mean & 20.3 & 21.7 & 17.9 & 24.3 & 21.2 & 22.8 & 21.8 & 14.5 \\
\hline
\end{tabular}

*Evaluation period: Nov. 2014 to Apr. 2015.

Table 2

Temperatures recorded during the red raspberry trial evaluation period in Santiago, Chile.

\begin{tabular}{|c|c|c|c|c|c|c|c|c|c|}
\hline \multirow[t]{2}{*}{ Temperature } & \multirow[t]{2}{*}{ Nov } & \multicolumn{2}{|c|}{ Dec } & \multicolumn{2}{|c|}{ Jan } & \multicolumn{2}{|c|}{ Feb } & \multirow[t]{2}{*}{ Mar } & \multirow[t]{2}{*}{ Apr } \\
\hline & & Control & Treatment & Control & Treatment & Control & Treatment & & \\
\hline Min. & 16.4 & 17.7 & 15.6 & 18.4 & 12.8 & 20.9 & 14.9 & 16.6 & 9.3 \\
\hline Max. & 23.1 & 25.7 & 23.2 & 26.3 & 17.5 & 24.8 & 24.8 & 23.2 & 17.5 \\
\hline Mean & 19.1 & 22.2 & 19.0 & 22.7 & 15.6 & 23.1 & 20.4 & 20.1 & 14.5 \\
\hline
\end{tabular}

*Evaluation period: Nov. 2015 to Apr. 2016.

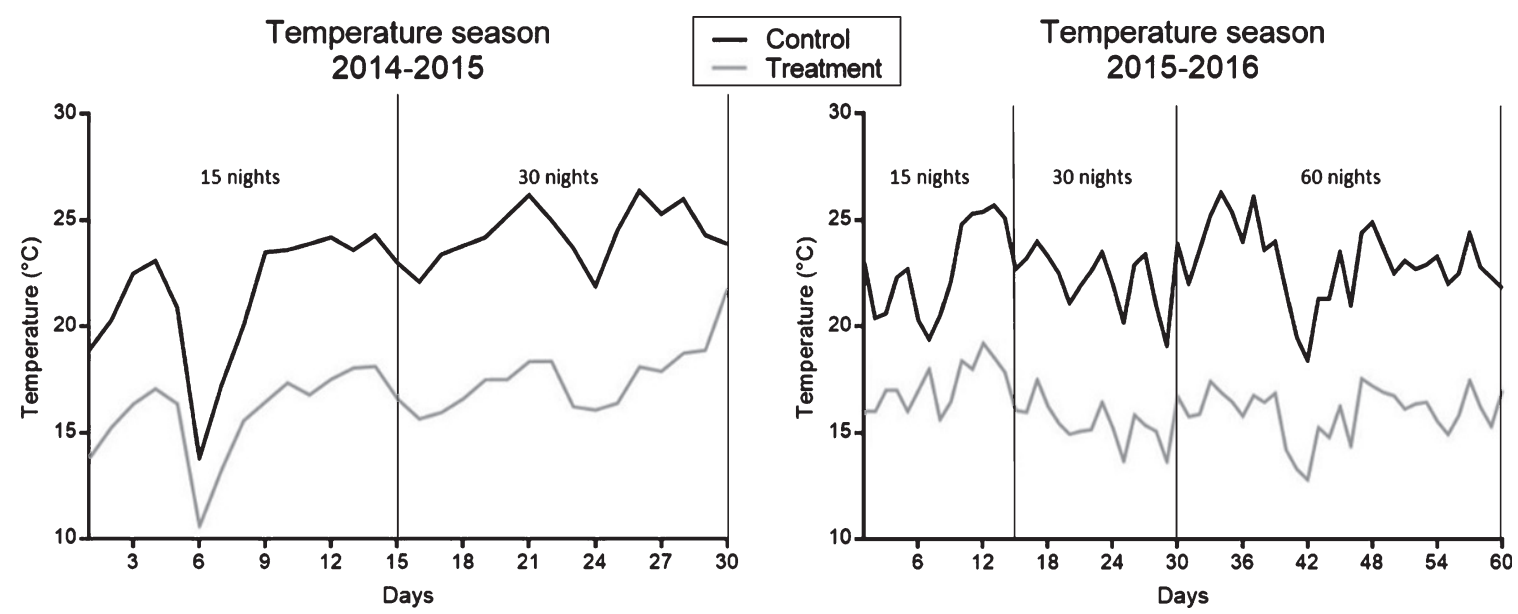

Fig. 1. Daily temperature from the beginning of the application of cold nights treatments, the period is indicated for 15 and 30 nights with and without cold in both seasons and 60 nights with and without cold in the second season.

\subsection{Molecular analysis}

Molecular analysis was performed during the second evaluation season. For the RNA extraction and cDNA synthesis, 3 samples were collected per treatment, using the first five buds from the apex downwards. Each sample consisted of approximately 40 ' $\mathrm{mg}$ of tissue from the 5 buds. The samples were collected at the inception of each treatment, on nights $0,15,30$ and 60 at 11:00 AM, and the samples were immediately frozen in liquid nitrogen and stored at $-80^{\circ} \mathrm{C}$. Control plants without cold treatments were grown outside the cold chambers, to obtain samples for gene expression (three plants for each sampling time). 
The total RNA was extracted from each sample using the $3 \%$ cetyl trimethyl ammonium bromide (CTAB) protocol [26], quantified using a NanoDrop 1000 spectrophotometer (Thermo Scientific) and visualised by electrophoresis to ensure its integrity. The RNA was then treated with DNase (Promega) using 1.6'mg of RNA as a template to synthesise the cDNA using Moloney murine leukaemia virus reverse transcriptase (RT-MMLV; Promega) and Oligo primers (dT). The total RNA from each biological replicate was used as a template for two $25-\mu \mathrm{L}$ reaction mixtures.

To obtain the TFL1 gene sequence from the raspberries based on orthologous genes from Fragaria vesca (JN172097.1, National Center for Biotechnology Information [NCBI]) and Fragaria $\mathrm{x}$ ananassa (AB822995.1, LC017718.1, NCBI), primers were designed with the sequences, 5'-ATGGCAAGAATGTCGGAA-3' and 5'CTAGCGTCTTCTTGCTGC-3'. A band of approximately 500'bp was amplified by PCR from the cDNA of the cvs. 'Heritage' and 'Meeker'. This band was then purified using the Wizard®SV Gel and PCR Clean-Up System kit (Promega) to be cloned in bacteria with the Topo vector, pUC18. Three transformed colonies were randomly selected and, using a miniprep, the plasmid was extracted with the segment of interest, which was then sequenced.

The TFL1 sequence for Rubus idaeus (RiTFL1) was recorded in NCBI with the code MF156853. This sequence was used to design primers for expression analysis (qRT-PCR) using the Primer3 Program. Secondary structure and energy diagram of each primer were tested on the mFold webserver. Finally, BLAST search was performed in NCBI to ensure specificity of each primer with the sequences $5^{\prime}$-ATCGGCATCCACAGGTTT- $3^{\prime}$ and $5^{\prime}$ CTCTCTGCGCATTGAAGT-3'.

For transcriptional analysis, $1 \mu \mathrm{L}$ of cDNA was used in the SYBR Green RT-PCR, with $10 \mu \mathrm{L}$ of Brilliant ${ }^{\circledR}$ II SYBR ${ }^{\circledR}$ Green QPCR Master Mix (Stratagene, Agilent Technologies) and 5'M of each primer in the Mx3000 thermal cycler (Stratagene). The thermal profile used for the amplification was $95^{\circ} \mathrm{C}$ for $10 \mathrm{~min}$, 40 cycles of $95^{\circ} \mathrm{C}$ for $30^{\prime} \mathrm{sec}, 60^{\circ} \mathrm{C}$ for $30^{\prime} \mathrm{sec}, 72^{\circ} \mathrm{C}$ for $30^{\prime}$ 'sec, and a melting curve from $55^{\circ} \mathrm{C}$ to $95^{\circ} \mathrm{C}$ with $0.5^{\circ} \mathrm{C}$ increases. Each reaction was performed with two technical replicates, and a water sample was included as the negative control.

The Ct value (threshold cycle value) was determined for each sample. Thus, $\mathrm{Ct}$ values were normalised using the Ct values of the raspberries' histone3 (H3) gene (AF304365.1). The primers used for this gene were 5'GAACTGTTGCTCTCCGTG-3' and 5'-GAAACGCAGGTCAGTCTT-3', yielding a nonsignificant variation in the gene expression after the treatments were applied to the plants. The normalised $\mathrm{Ct}$ values were used to determine the times when the RiTFL1 gene expression changed [27].

\subsection{Statistical analysis}

A completely randomized experimental design was used, with four and five replicates in the first year and second year of evaluation, respectively, with one plant as an experimental unit in both cases. For molecular analyses, three replicates were used with one plant as an experimental unit. Analysis of variance was performed for each parameter evaluated per genotype. The means between the genotypes according to treatment were compared using the least significant difference (LSD) test with a significance level of $p=0.05$. The program Statistic 9 [28] was used for statistical analysis.

\section{Results}

\subsection{Flowering parameters}

The evaluated parameters (Table 3) shows that low night temperature during the two seasons was improved the flowering in the two primocane cultivars 'Autumn Bliss' and 'Heritage'. For 'Autumn Bliss', the number of 
Table 3

Effect of low temperature at night on flowering in two primocane cultivars in two seasons.

\begin{tabular}{|c|c|c|c|c|c|c|c|}
\hline \multirow[t]{2}{*}{ Cultivar } & \multirow{2}{*}{$\begin{array}{c}\text { Length of } \\
\text { temperature } \\
\text { treatment (days) }\end{array}$} & \multicolumn{2}{|c|}{$\begin{array}{c}\text { No. of floral lateral } \\
\text { shoots }\end{array}$} & \multicolumn{2}{|c|}{$\begin{array}{c}\text { Total number of } \\
\text { flowers }\end{array}$} & \multicolumn{2}{|c|}{$\begin{array}{l}\text { No. of days to the first } \\
\text { visible floral bud }\end{array}$} \\
\hline & & 2015 & 2016 & 2015 & 2016 & 2015 & 2016 \\
\hline \multirow[t]{3}{*}{ Autumn Bliss } & 0 & $12.5 \mathrm{~b}$ & $13.2 \mathrm{~b}$ & $85.3 \mathrm{~b}$ & $95.2 \mathrm{~b}$ & $50.3 \mathrm{a}$ & $40.4 \mathrm{a}$ \\
\hline & 15 & $15.0 \mathrm{a}$ & $14.0 \mathrm{ab}$ & $125.0 \mathrm{a}$ & $118.0 \mathrm{ab}$ & $40.8 \mathrm{~b}$ & $45.8 \mathrm{a}$ \\
\hline & 30 & $15.5 \mathrm{a}$ & $15.6 \mathrm{a}$ & $125.3 \mathrm{a}$ & $142.0 \mathrm{a}$ & $46.8 \mathrm{ab}$ & $44.4 \mathrm{a}$ \\
\hline \multirow[t]{3}{*}{ Heritage } & 0 & $12.0 \mathrm{~b}$ & $13.2 \mathrm{~b}$ & $61.0 \mathrm{a}$ & $90.4 \mathrm{a}$ & $85.8 \mathrm{a}$ & $67.0 \mathrm{a}$ \\
\hline & 15 & $12.8 \mathrm{ab}$ & $13.2 \mathrm{~b}$ & $63.8 \mathrm{a}$ & $89.4 \mathrm{a}$ & $86.0 \mathrm{a}$ & $64.6 \mathrm{a}$ \\
\hline & 30 & $14.5 \mathrm{a}$ & $15.0 \mathrm{a}$ & $89.8 \mathrm{a}$ & $114.0 \mathrm{a}$ & $63.5 \mathrm{~b}$ & $57.6 \mathrm{a}$ \\
\hline
\end{tabular}

*The data are the average of four replications in first season and five replications for second season, each represented by one plant. 'Different letters within the columns indicate significant differences $(p<0.05)$ according to the LSD test (the comparison was made for each cultivar according to the treatment and was not compared between cultivars).

floral laterals and total flowers per plant were greater at 15 and 30 cold night treatment compared to the control. In addition, the number of days until the first floral bud appeared was lower in the first season.

In 'Heritage', the 30-night treatment increased the number of floral laterals and total flowers per plant and decreased the number of days until the first floral bud appeared. However, this response was not significant for the 15-night treatment, that is, in contrast to 'Autumn Bliss', 'Heritage' required several cold nights to improve and anticipate flowering.

For the floricane cultivars 'Meeker' and 'Tulameen', only 'Meeker' responded to the 60-night treatment by flowering before the end of the season. For this treatment, 'Meeker' plants produced an average of 13 floral laterals and 63.5 flowers per plant. The first visible floral bud was obtained 95 days after planting. Although flower buds could be observed at the end of the season, flowering occurred only in the upper part of the shoot, which is typically referred to as tip-flowering (Fig. 2).

To evaluate whether the buds below the last developed floral lateral had initiated flowere, a morphological meristematic analysis was conducted for each treatment, using a $63 \times$ magnifying glass. Table 4 shows the number of non-breaking generative buds at the end of season, as well as total generative buds (number of floral laterals plus the number of non-breaking buds) per treatment per cultivar.

In 'Autumn Bliss', there was no difference between the number of breaking buds for the different treatments. But, when considering the total number of generative buds (breaking and non-breaking buds with flowers initiated), the 15- and 30-night treatments showed increased proportions generative buds, but only the 30-night treatment showed a statistically significant difference when compared to the control (Table 4).

'Heritage' differed significantly in the number of non-breaking generative buds, which was greater in the 15and 30-night treatments compared with the control. However, only the number of floral laterals for the 30-night treatment differed significantly from the control.

For the floricane cultivar, 'Meeker', all treatments initiated floral buds, but only the 60-night treatment differed significantly from the other treatments. In addition, the 60-night-treated plants produced laterals; therefore, considering the buds that differentiated to reproductive and floral laterals, this difference was also significant. 'Tulameen' only presented differentiated buds for the 60-night treatment.

Figure 3 shows schematic drawings of the plants and their bud state at the end of the growth season. In the primocane cultivars, the floral laterals developed, but several generative buds did not break into flowering laterals, and a proportion of the buds remained vegetative upon entering dormancy/recess.

The floricane cultivars clearly differed, where 'Meeker' was taller with non-breaking generative buds and flowering occurred at the shoot tip, while 'Tulameen' presented fewer differentiated buds and with no open flowers. 


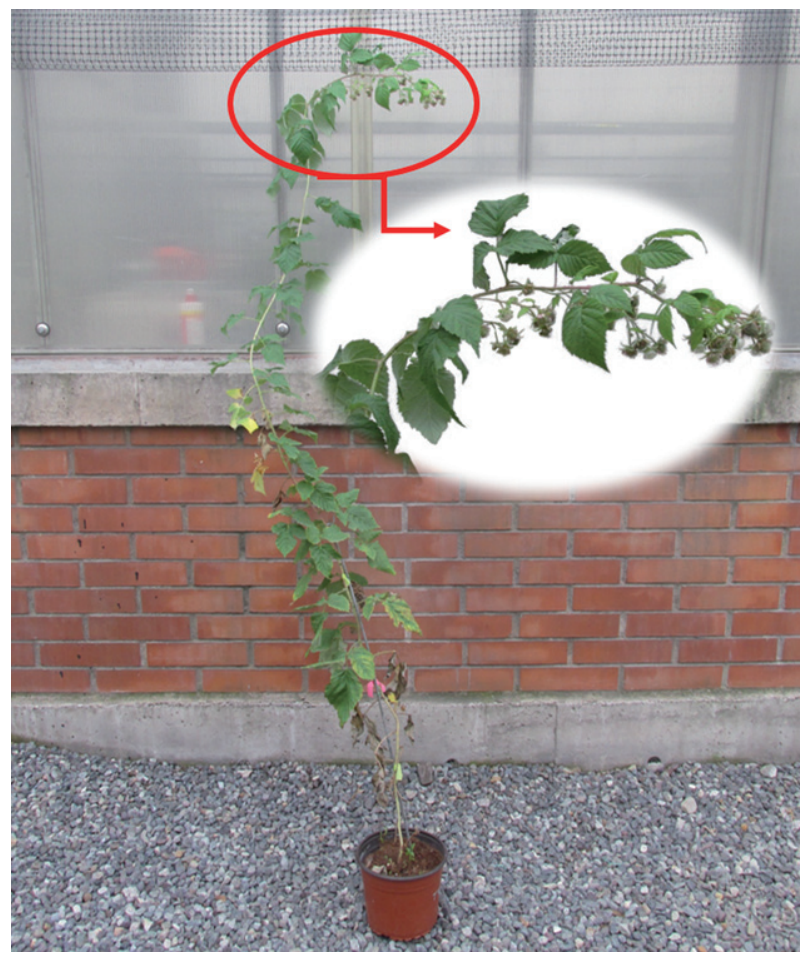

Fig. 2. Cultivar 'Meeker' after 60-nights of cold treatment featuring flowering and fruiting before winter recess.

Table 4

Number of generative/reproductive buds at the end of the season for four raspberry cultivars with different length of cold treatment as indicated. The first column shows the number of generative non-breaking buds and the second column presents the total number of generative buds (breaking and non-breaking floral buds).

\begin{tabular}{|c|c|c|c|c|c|c|c|c|}
\hline \multirow{2}{*}{$\begin{array}{l}\text { Length of } \\
\text { temperature } \\
\text { treatment } \\
\text { (days) } \\
\end{array}$} & \multicolumn{2}{|c|}{ 'Autumn Bliss' } & \multicolumn{2}{|c|}{ Heritage } & \multicolumn{2}{|c|}{ Meeker } & \multicolumn{2}{|c|}{ Tulameen } \\
\hline & $\begin{array}{l}\text { Non-breaking } \\
\text { buds }\end{array}$ & $\begin{array}{c}\text { Total } \\
\text { reproductive } \\
\text { buds }\end{array}$ & $\begin{array}{c}\text { Non- } \\
\text { breaking } \\
\text { buds }\end{array}$ & $\begin{array}{c}\text { Total } \\
\text { reproductive } \\
\text { buds }\end{array}$ & $\begin{array}{c}\text { Non- } \\
\text { breaking } \\
\text { buds }\end{array}$ & $\begin{array}{c}\text { Total } \\
\text { reproductive } \\
\text { buds }\end{array}$ & $\begin{array}{l}\text { Non-breaking } \\
\text { buds }\end{array}$ & $\begin{array}{c}\text { Total } \\
\text { reproductive } \\
\text { buds }\end{array}$ \\
\hline 0 & $8.7 \mathrm{a}$ & $22.7 \mathrm{~b}$ & $1.0 \mathrm{~b}$ & $14.3 \mathrm{~b}$ & $20.7 \mathrm{~b}$ & $20.7 \mathrm{~b}$ & $0.0 \mathrm{~b}$ & . \\
\hline 15 & $9.0 \mathrm{a}$ & $23.0 \mathrm{ab}$ & $2.7 \mathrm{a}$ & $15.7 \mathrm{ab}$ & $18.3 \mathrm{~b}$ & $18.3 \mathrm{~b}$ & $0.0 \mathrm{~b}$ & . \\
\hline 30 & $10.0 \mathrm{a}$ & $26.7 \mathrm{a}$ & $3.0 \mathrm{a}$ & $18.3 \mathrm{a}$ & $23.0 \mathrm{~b}$ & $23.0 \mathrm{~b}$ & $0.0 \mathrm{~b}$ & \\
\hline 60 & . & . & . & . & $30.0 \mathrm{a}$ & $38.7 \mathrm{a}$ & $4.3 \mathrm{a}$ & . \\
\hline
\end{tabular}

${ }^{*}$ The data are the average of three replications in two seasons, each represented by one plant. 'Different letters within the columns indicate significant differences $(p<0.05)$ according to the LSD test.

\subsection{Vegetative growth}

Shoot growth in all cultivars featured a simple sigmoid curve. 'Autumn Bliss' and 'Heritage' reached nearly a height of 2 and $2.5 \mathrm{~m}$, respectively, during the first season, while during the second season, both cultivars reached approximately $1.60 \mathrm{~m}$. In general, the plants subjected to cold treatment grew slightly less than the control plants. 

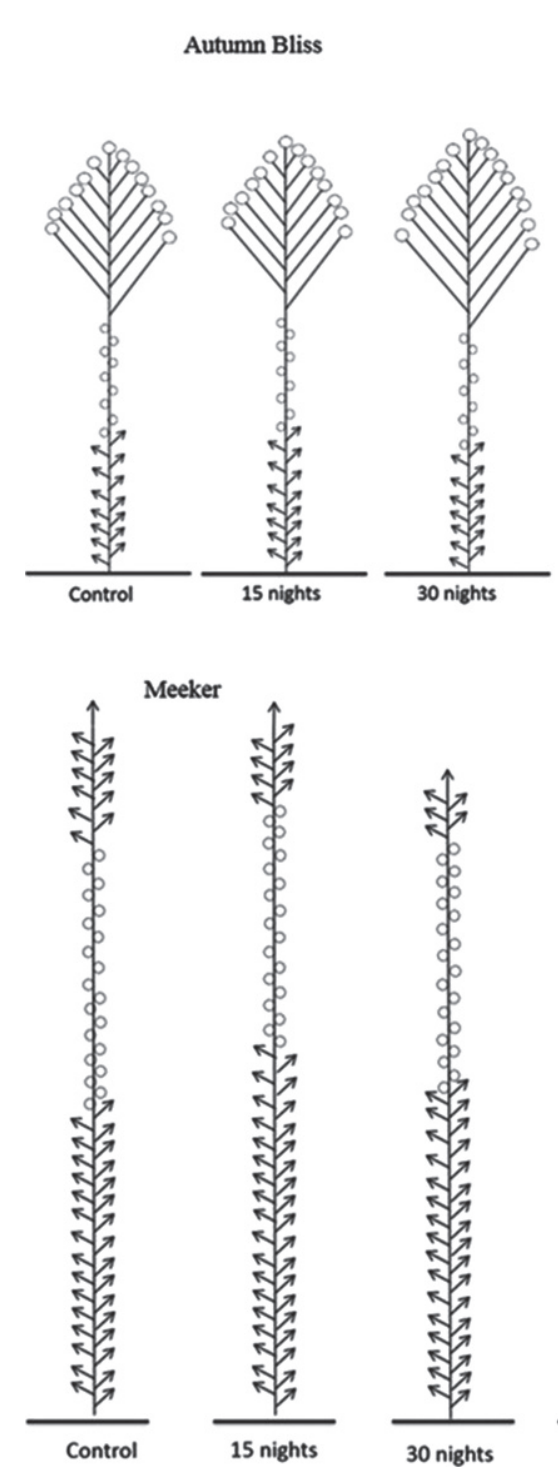
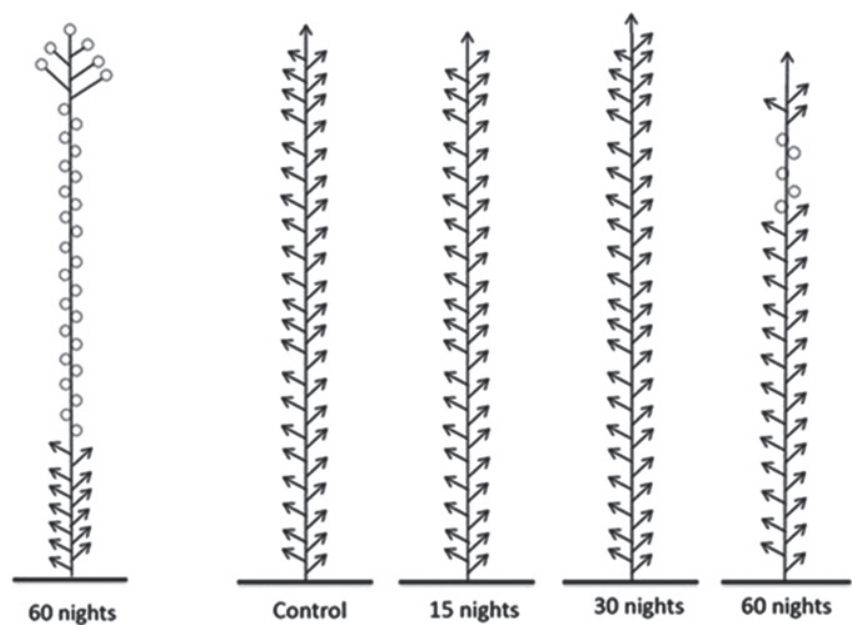

Fig. 3. Bud state along the seasonal shoot, from the apex to the base, at the end of the growth season and beginning of winter recess for four raspberry cultivars and different length of temperature treatments as indicated. The meristematic analysis was carried out in three plants for each cultivar and temperature treatment.

Figure 4 shows growth curves for the primocane cultivars for the different treatments; the vertical line marks the moment at which the first floral bud appeared at the apex. In the treatments applied in 'Heritage' the flowering was anticipated and the cessation of growth in relation to the control treatment.

The floricane cultivar, 'Meeker', grew tallest, with individual shoots reaching more than $5 \mathrm{~m}$ in the first season, and growth arrest came late in the season (Fig. 5). Plants subjected to the 60-night cold treatment were shorter and 

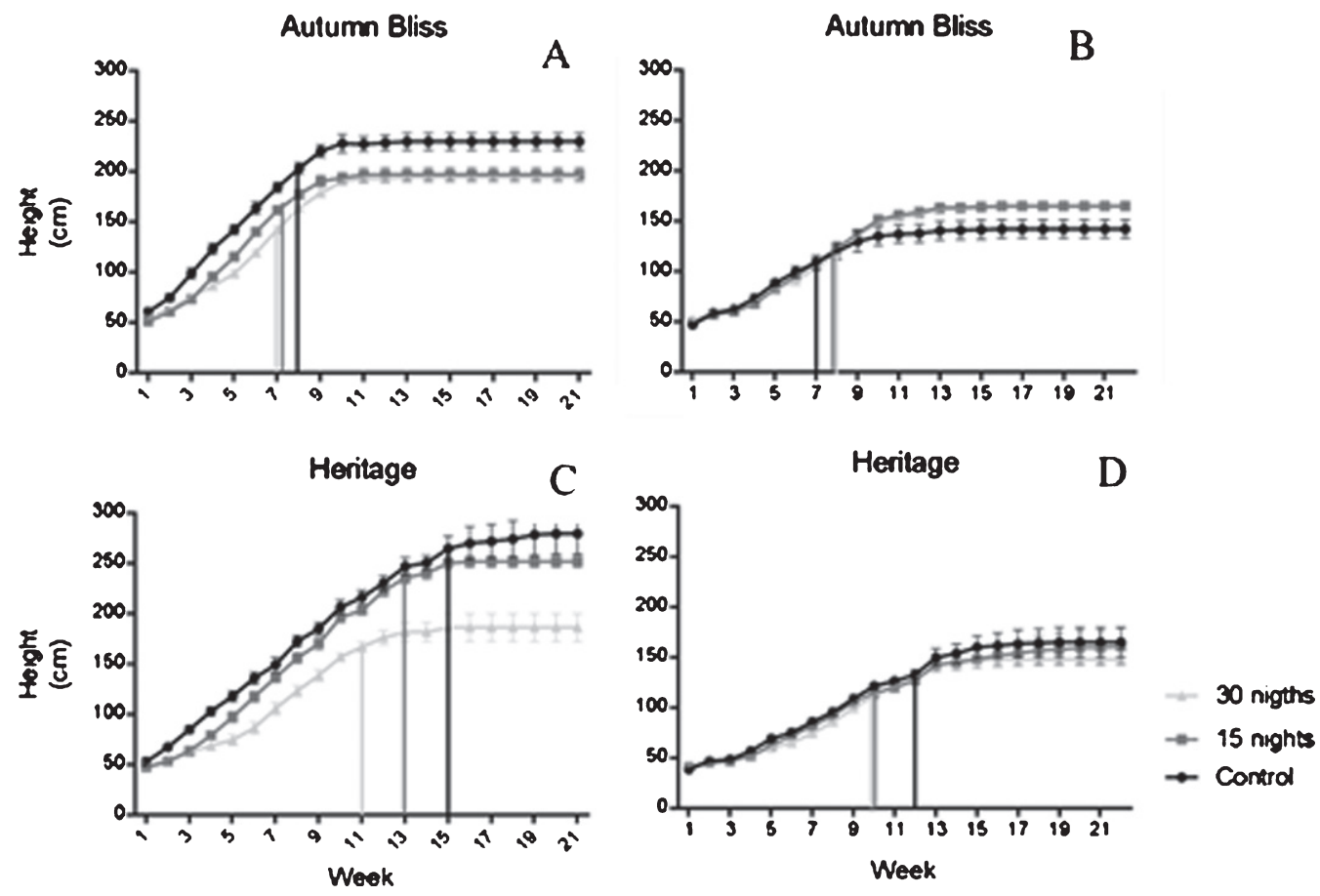

Fig. 4. Time course of shoot elongation growth in two primocane raspberry cultivars with different length of temperature treatment in two seasons (Panels A and C; 2015, and B and D; 2016). The solid lines indicate time for first visible floral bud appearance \pm SE

flowered before entering dormancy. 'Tulameen' was shorter than 'Meeker', and the control plants were shorter than the treated plants.

In 'Autumn Bliss' shoot growth in the treated plants differed significantly compared to the control for each cultivar's final height in the first season (Table 5), where the plants submitted to the 15- and 30-night cold treatments were shorter, contrasting with the second season, where the control-treated plants were the shortest. The same trend occurred for the number of nodes.

'Heritage' grew significantly less only in the 30-night cold treatment in the first season, while the second season showed no differences between treatments. The number of nodes formed did not significantly differ between seasons (Table 5).

In 'Meeker', cold treatment clearly affected height and numbers of nodes. For the first season, the 30-nighttreated plants were significantly shorter than those of the other treatments. This effect was not seen in the number of nodes formed (Table 5). In the second season, only the 60-night cold-treated plants were significantly shorter. The number of buds was significantly lower only in the 60-night treatment in the second season.

In 'Tulameen', control treatment had the shortest plants, while the 30-night cold treatment presented the tallest plants; the 15- and 60-night cold treatments did not significantly differ, not did the number of buds (Table 5).

\subsection{Analysis of the TFL1 (flowering) repressor gene}

Firstly, the TFL1 gene sequence was identified for the raspberry, using primers based on the gene's orthologous sequences in Fragaria vesca and $F$. ananassa. RNA samples from the 'Heritage' and 'Meeker' cultivars were used, being $100 \%$ homologous sequences in both cases. The obtained sequence was recorded under the code MF156853 in the NCBI database. 


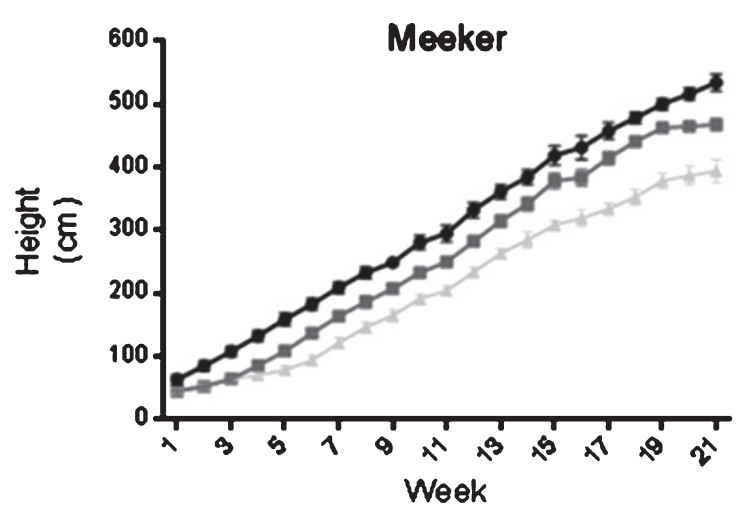

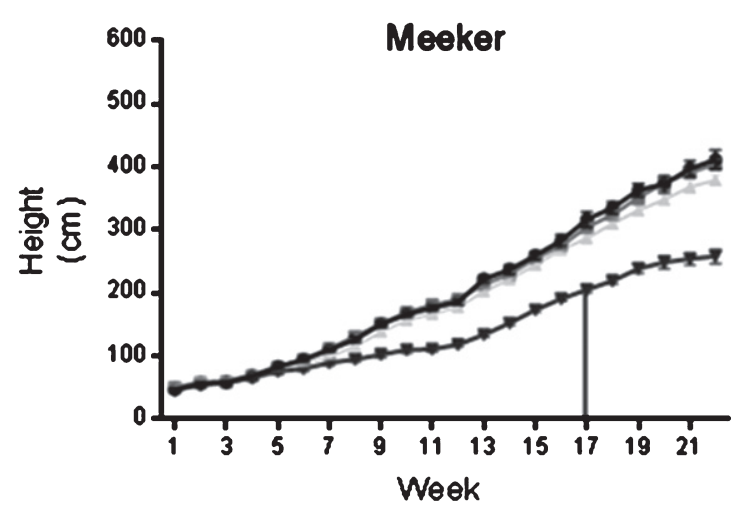

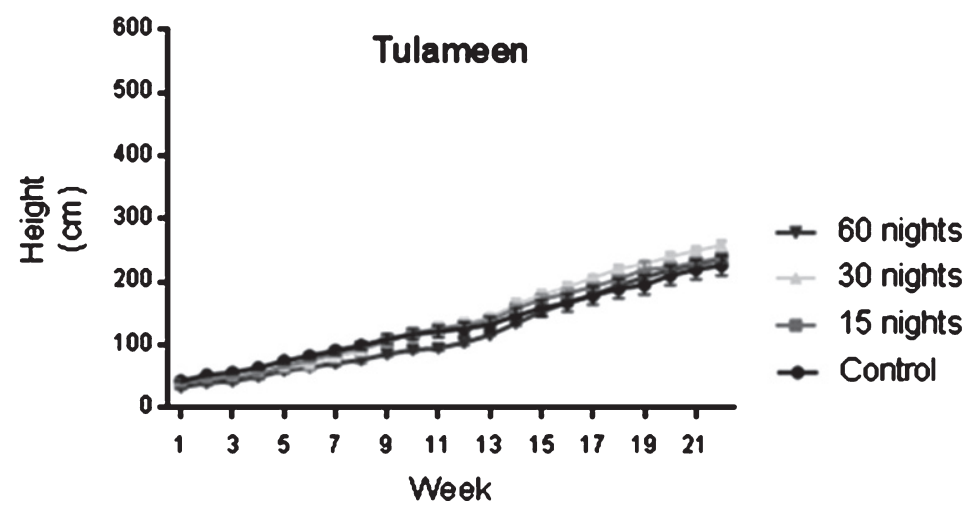

Fig. 5. Time course of shoot elongation growth in two floricane cultivars according to treatment for the two evaluation seasons for 'Meeker' (A 2015 and B 2016) and season 2016 for 'Tulameen' (C). The line indicates when the first visible floral bud appeared for the second evaluation season in 'Meeker'.

This sequence was compared with other TFL1 sequences in different species of the Rosaceae family, yielding the phylogenetic tree in Fig. 6, which shows similarities mainly with the genus Fragaria.

The mRNA sequence alignments, translated to proteins, were highly homologous $(91 \%)$ between the sequences Fragaria $\times$ Ananassa, Fragaria vesca and Prunus serotina, relative to the sequence of Rubus idaeus (Fig. 7).

Figure 8 shows gene expression levels over time for the TFL1 gene sequence in Rubus idaeus for each cultivar and treatment. In 'Autumn Bliss', RiTFL1 was repressed, and the cold-treated plants did not significantly differ compared with the controls. In 'Heritage', the gene was expressed in the control plants, while it was repressed in the treated plants; however, genic expression did not differ between the 15- and 30-night treatments.

Among the floricane cultivars, 'Meeker' presented an initial RiTFL1 expression that decreased after 60 days, with increased gene repression in the cold-treated plants. In 'Tulameen', the RiTFL1 gene expression was only detected in the control treatment. In the 15-, 30-, and 60-night cold-treated plants, as well as in the 30- and 60-night control plants, the gene was repressed with no significant differences.

\section{Discussion}

Results indicate that low nocturnal temperatures modified flowering and growth of the seasonal shoot. Low temperatures positively affected the red raspberries, mainly by shortening the vegetative period and accelerating 
Table 5

Effect of low night temperature during the growth phase on shoot height and node number at the end of the season in four raspberry cultivars in two years.

\begin{tabular}{|c|c|c|c|c|c|}
\hline \multirow[t]{2}{*}{ Cultivar } & \multirow{2}{*}{$\begin{array}{c}\text { Length of } \\
\text { temperature } \\
\text { treatment (days) }\end{array}$} & \multicolumn{2}{|c|}{ Shoot height $(\mathrm{cm})$} & \multicolumn{2}{|c|}{ No. of nodes } \\
\hline & & $2014-2015$ & $2015-2016$ & $2014-2015$ & $2015-2016$ \\
\hline \multirow[t]{3}{*}{ 'Autumn Bliss' } & 0 & $229.8 \mathrm{a}$ & $142.2 \mathrm{~b}$ & $47.8 \mathrm{a}$ & $36.4 \mathrm{~b}$ \\
\hline & 15 & $197.0 \mathrm{~b}$ & $164.8 \mathrm{a}$ & $42.0 \mathrm{~b}$ & $39.0 \mathrm{ab}$ \\
\hline & 30 & $194.3 \mathrm{~b}$ & $165.2 \mathrm{a}$ & $42.8 \mathrm{~b}$ & $39.8 \mathrm{a}$ \\
\hline \multirow[t]{3}{*}{ Heritage } & 0 & $279.5 \mathrm{a}$ & $165.2 \mathrm{a}$ & $73.8 \mathrm{a}$ & $49.0 \mathrm{a}$ \\
\hline & 15 & $251.8 \mathrm{a}$ & $160.8 \mathrm{a}$ & $67.0 \mathrm{a}$ & $49.2 \mathrm{a}$ \\
\hline & 30 & $186.3 \mathrm{~b}$ & $148.0 \mathrm{a}$ & $53.0 \mathrm{~b}$ & $44.0 \mathrm{a}$ \\
\hline \multirow[t]{4}{*}{ Meeker } & 0 & $504.3 \mathrm{a}$ & $399.0 \mathrm{a}$ & $94.8 \mathrm{a}$ & $86.6 \mathrm{a}$ \\
\hline & 15 & $413.5 \mathrm{ab}$ & $396.0 \mathrm{a}$ & $85.3 \mathrm{a}$ & $85.2 \mathrm{a}$ \\
\hline & 30 & $370.3 \mathrm{~b}$ & $375.4 \mathrm{a}$ & $80.8 \mathrm{a}$ & $81.6 \mathrm{a}$ \\
\hline & 60 & . & $260.0 \mathrm{~b}$ & . & $67.6 \mathrm{~b}$ \\
\hline \multirow[t]{4}{*}{ Tulameen } & 0 & . & $208.4 \mathrm{~b}$ & . & $60.2 \mathrm{a}$ \\
\hline & 15 & . & $240.0 \mathrm{ab}$ & . & $69.4 \mathrm{a}$ \\
\hline & 30 & . & $260.6 \mathrm{a}$ & . & $72.4 \mathrm{a}$ \\
\hline & 60 & . & $237.6 \mathrm{ab}$ & . & $67.0 \mathrm{a}$ \\
\hline
\end{tabular}

*The data are the average of four replications in first season and five replications for second season, each represented by one plant. 'Different letters within the columns indicate significant differences $(p<0.05)$ according to the LSD test (the comparison was made for each cultivar according to the treatment, and was not compared between cultivars).

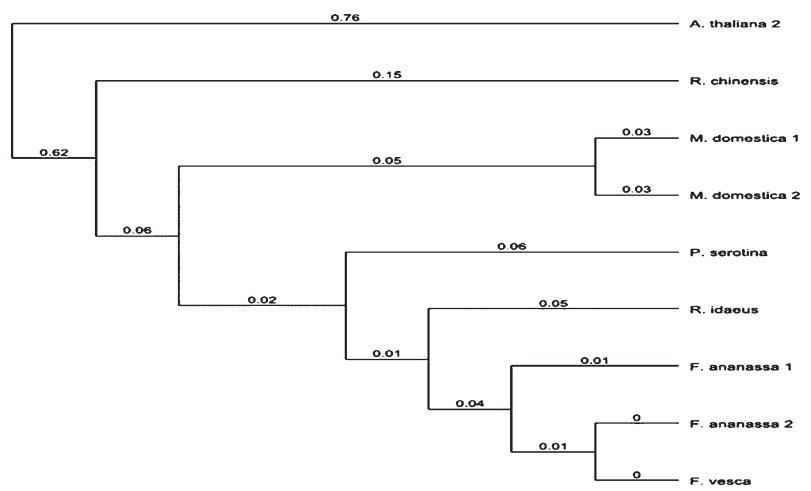

Fig. 6. The phylogenetiv analysis of TFL1 mRNA nucleotide sequence in Rosaceae species and Arabidopsis thaliana (KX139000.1). The abbreviations correspond to Rosa chinensis (JQ008813.1), Malus domestica (NM_001293865.1 and NM_002293958.1), Prunus serotina (KY435487.1), Rubus idaeus (MF156853), Fragaria x ananassa (KR139757.1 and LC017718.1) and Fragaria vesca (NM_001280077.1). Phylogenetic relationship tree constructed using Geneious program v. 9.1.4, UPGMA tree.

floral induction and differentiation [29, 30, 31]; this study the flowering was improved under cold conditions only at night, simulating a greater thermal day-night oscillation.

Within cultivars, the onset of flowering can vary significantly from year to year and from one location to another. In red raspberries, the cycles are controlled mainly by photoperiod and temperature [10]. 'Heritage' 


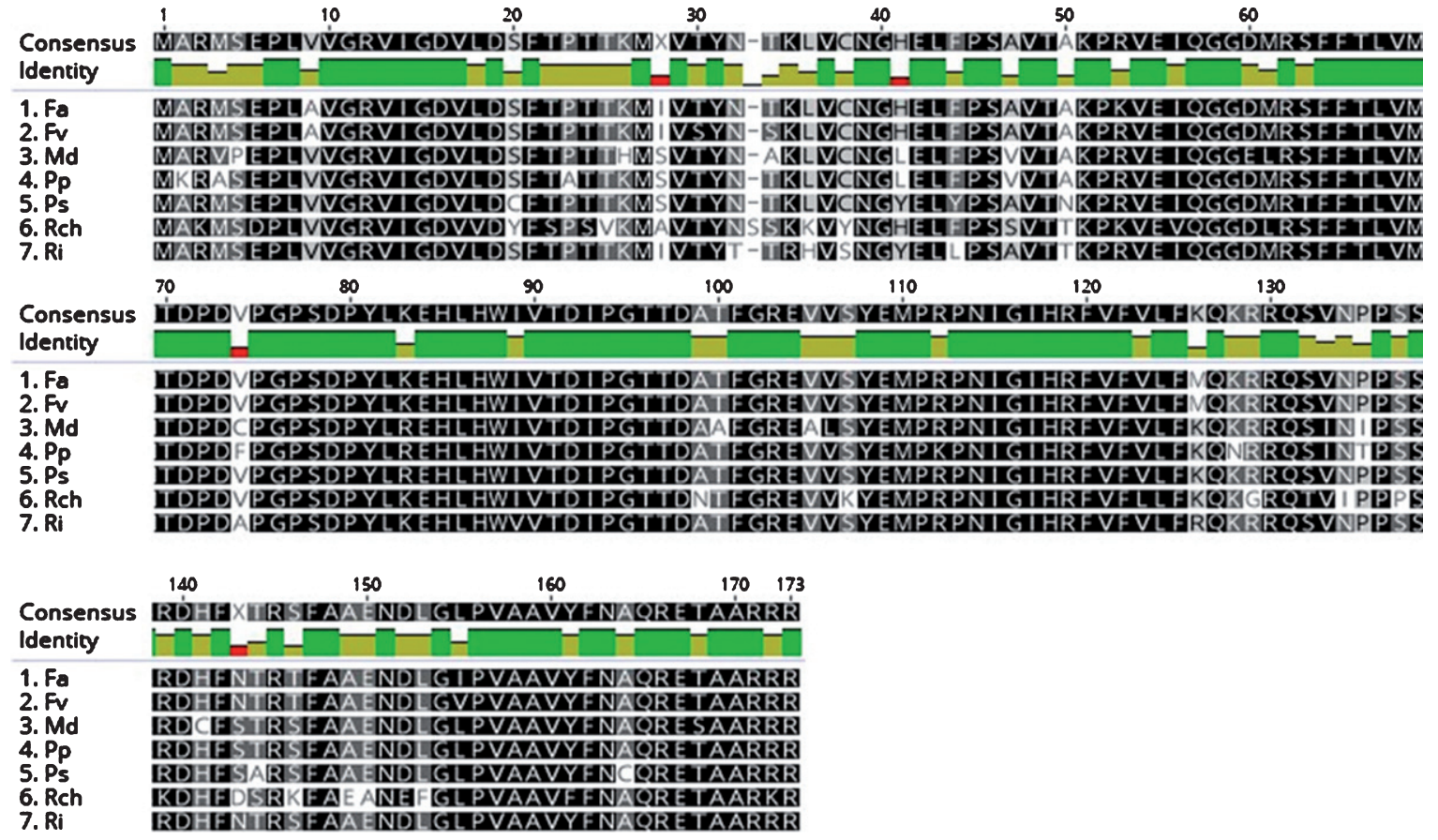

Fig. 7. The protein aligment of traduction of TFL1 mRNA nucleotide sequence in Rosaceae species. The abbreviations correspond to Fragaria x ananassa (AMR34693.1), Fragaria vesca (NP_001267006.1), Malus domestica (NP_001280794.1), Pyrus pyrifolia (BAJ33557.1), Prunus serotina (AQX77700.1), Rosa chinensis (JQ008813.1) and Rubus idaeus (MF156853). Protein aligment was constructed using Geneious program v. 9.1.4.

loses its primocane-fruiting trait in temperate areas with low thermal oscillations [4]. This is consistent with the results of the present study, since we found that this cultivar responded better to cold treatments (Table 4). In contrast, 'Autumn Bliss' behaves more uniformly in terms of flowering, and while cold treatments enhanced flowering, this effect was less marked than in 'Heritage'.

Several authors have indicated that floricane cultivars require low temperatures for floral induction $[1,9,10$, $11,32]$, while primocane cultivars can flower at relatively warm temperatures [12, 33, 34]. We found that while 'Autumn Bliss' and 'Heritage' are classified as primocane cultivars, their response to cold differed, 'Heritage' showing a better response to the cold treatments.

In the floricane cultivars, only 'Meeker' flowering was enhanced by cold, but it needed a longer exposure time at low temperatures to achieve significant results. With the 60-night cold treatment, it behaved like a primocane cultivar, which is similar to findings by [25], in which the cultivar 'Lagorai' behaved intermediately between the primocane cultivar 'Erika' and the floricane cultivar 'Tulameen'. Meristematic evaluation of the undeveloped buds at the end of the season showed that in 'Heritage', 'Meeker' and 'Tulameen', cold treatment favoured bud differentiation (Table 4).

Nocturnal cold in the middle of the growing season favours both primocane and floricane cultivars in different flowering aspects. Low temperatures enhance flowering in red raspberries, that is, they respond to vernalisation, as reported by [10]. This process may have quantitative cold requirements since plants responded differently depending on the cold treatment applied to the cultivar. The different cold requirements for vernalisation may generate the two flowering behaviours described in raspberries.

Red raspberry flowering is followed by growth arrest. In primocane cultivars, this growth arrest occurs early in the season, while in floricane cultivars, growth cessation is associated with shorter days and lower temperatures 

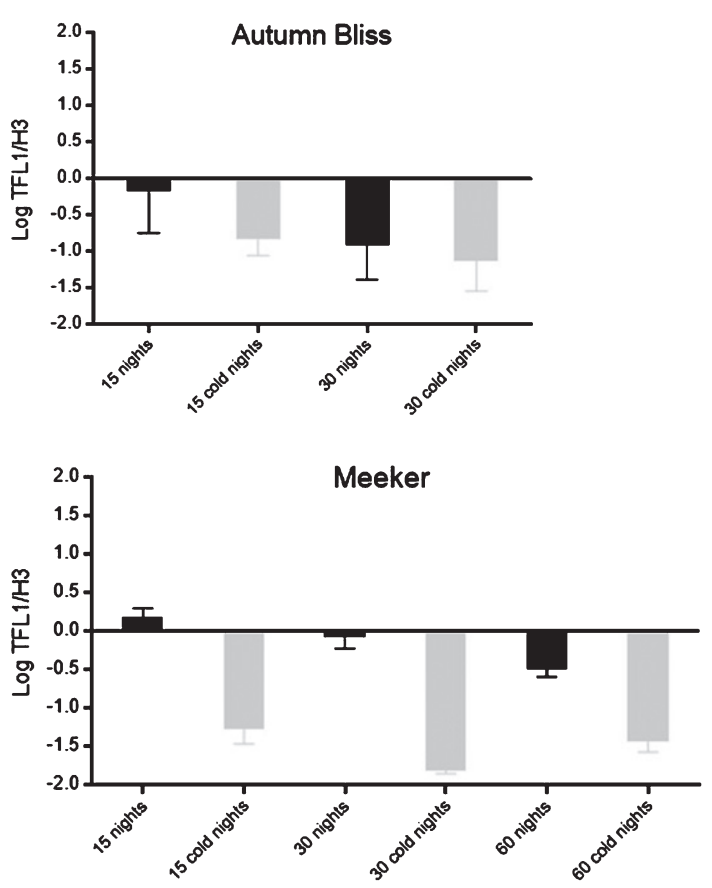
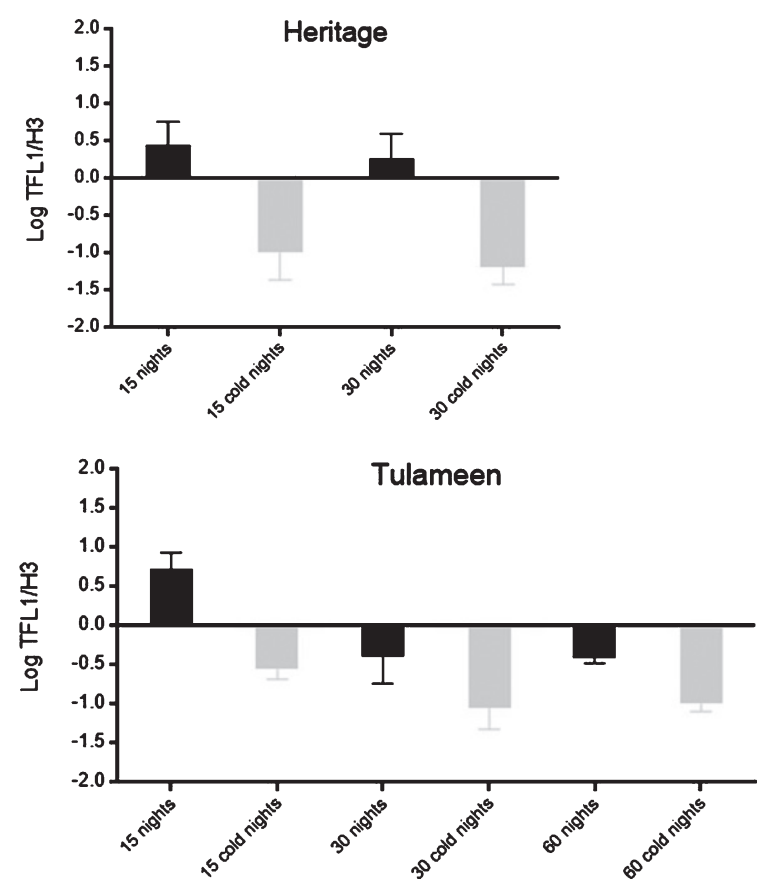

Fig. 8. TFL1 gene expression in the raspberry cvs. 'Autumn Bliss', 'Heritage', 'Meeker' and 'Tulameen'. Gene expression was measured during the shoot growth period(phase?) from the beginning of cold treatments; thus, the gene expression was evaluated at 15, 30 and 60 days (the latter only in the floricane cultivars) with and without cold night treatments. Relative gene expression with the same letter indicates no significant difference, with $p \geq 0.05$. \pm SE.

[1]. In deciduous plants, nocturnal temperatures impact growth arrest relative to day temperatures, since low temperatures induce growth arrest under long-day conditions [35]. This dynamic could be related to the less height of the treated plants, primocane and floricane cultivars were shorter at the end of the evaluation period in the first season (Table 5). This effect was also observed by [13] in the 'Autumn Bliss' cultivar, as these authors pointed out that low temperatures would act in two ways, affecting the time of floral induction and shoot growth rate. However, this difference was less marked in the second season, likely due to the difference in temperature/length of time between planting and growth arrest in the second season (Supplementary Table 1). In the second season, the control treatments in 'Autumn Bliss' and 'Tulameen' produced the shortest plants; therefore, this growth arrest occurred earlier than those of the other treatments; however, this was not related to flowering, and the 15- and 30-night cold treatments increased the number of floral laterals in 'Autumn Bliss' (Table 3), while in 'Tulameen', only the 60-night treatment had differentiated buds (Table 4) despite having a late growth arrest, reflected in its greater height.

In addition to the photoperiod and temperature effects on flowering [10], an important genetic factor would produce different responses to environmental factors. In the primocane cultivar, 'Autumn Treasure', high temperatures prior to flowering, delayed and suppressed this process; therefore, this cultivar would require lower temperatures for flowering. The authors related this phenomenon to the gene introgression of the species Rubus arcticus, into this cultivar's pedigree [33]. This is similar to that observed in 'Heritage' in climates with maritime influence and low thermal oscillation, where the lack of cold, rather than high temperatures, suppresses flowering. Temperature would have a dominant effect on photoperiod, and floral induction may occur within a certain temperature range [24]. 
When studying the influence of cold nights on RiTFL1 expression levels, we observed that cold inhibited RiTFL1 in all cultivars. However, in high primocane-fruiting cultivars such as 'Autumn Bliss', this gene was repressed regardless of cold treatment. In 'Heritage', a low primocane-fruiting cultivar, the gene was expressed in control plants, and repressed in those subjected to the cold treatments. RiTFL repression may have favoured early flowering in this trial, and plants developed more reproductive buds before entering recess. This agrees with the results of [15], who demonstrated that low temperatures are necessary to suppress TFL1 in Fragaria vesca, enabling the plants to induce flowering.

\section{Conclusion}

This study demonstrated that low night-time temperatures during the growth season favourably affected flowering, mainly in 'Heritage', a cultivar with low primocane fruiting, and enabled tip flowering in seasonal shoots of 'Meeker', a floricane cultivar. The behaviour, when grown in temperate climates with low day-night temperature oscillation, is that shoots of these cultivars require the exposure to low temperatures during development to repress the RiTFL1 gene, which enables floral induction, achieving flowering during the season before winter recess. Thus, cold requirements for vernalisation of the different genotypes, could explain the various phenotypes related to flowering, so that low temperatures reduce RiTFL1 expression in individuals with intermediate behaviour between primocane and floricane fruiting traits. Cultivars such as 'Autumn Bliss' show a more uniform flowering without being strongly affected by the environment, which allows the expansion of cultivation areas without risking primocane flowering. Establishing genetic differences between cultivars of the same species requires further studies to determine whether the control of seasonal shoot flowering by RiTFL1 is complemented by other minor modifiers. Verifying whether the expression of this gene is the main determinant of the degree of primocane-fruiting could enable its use as a selection marker in segregating populations, where high primocane-fruiting individuals are sought.

Obtaining genotypes that can flower without requiring exposure to low temperatures to trigger floral induction, is a primary selection characteristic, both to expand the cultivation areas and for off-season fruit production.

\section{Acknowledgments}

This study was supported by CONICYT: Scholarship, PCHA. No. 21130352 was provided to Elida Contreras Moya, GOODBERRY (European Union's Horizon 2020 research and innovation programme; grant agreement $\mathrm{N}^{\circ}$ 679303) and IT13I20045 FONDEF Project "Selection and recording of new raspberry varieties developed in Chile".

\section{Funding}

The authors report no funding.

\section{Conflict of interest}

The authors have no conflict of interest to report. 


\section{References}

[1] Heide O, Sønsteby A. Physiology of flowering and dormancy regulation in annual - and biennial-fruiting red raspberry (Rubus idaeus L.) - a review. Journal of Horticultural Science \& Biotechnology. 2011;86(5):433-42.

[2] Pritts M. Primocane-fruiting raspberry production. HortScience. 2008;43(6):1640-1.

[3] Oliveira P, Oliveira C, López-da-Fonseca L, Monteiro A. Off-season production of primocane-fruiting red raspberry using summer pruning and polyethylene tunnels. HortSciencie. 1996;31(5):805-7.

[4] Gambardella M, Contreras E, Alcalde J, Neri D. Phenotyping primocane fruiting trait in raspberry (Rubus idaeus L.). Acta Horticulturae. 2016;1133:67-74.

[5] Daubeny H, Maloney K, McGregor G. 'Heritage' red raspberry. Fruit Var J. 1992;46:2-3.

[6] Leiva C, Schmidt C, Gajardo G. Manual técnico y productivo y económico bajo condición actual y clima proyectado al 2030. Ciren $\mathrm{N}^{\circ}$. 2017;204:20-1.

[7] Keep E. Primocane (autumn)-fruiting raspberries: A review with particular reference to progress in breeding. J Hort Sci. 1988;63:1-18.

[8] Keep E. Autumn-fruiting in raspberries. J Hort Sci. 1961;36:174-85.

[9] Sønsteby A, Heide OM. Environmental control of growth and flowering of Rubus idaeus L. cv 'Glen Ample'. Scientia Horticulturae. 2008;117:249-56.

[10] Carew J, Gillespie T, White T, Wainwright H, Brennan R, Battey N. The control of the annual growth cycle in raspberry. Journal of Horticultural Science \& Biotechnology. 2000;75:495-503.

[11] Dale A. Raspberry production in greenhouse: Physiological aspects. Acta Horticulturae. 2008;777:219-23.

[12] Sønsteby A, Heide OM. Effects of photoperiod and temperature on growth and flowering in the annual (primocane) fruiting raspberry (Rubus idaeus L.) cultivar 'Polka'. Journal of Horticultural Sciencie \& Biotechnology. 2009;84:439-46.

[13] Carew J, Mahmood K, Darby J, Hadley P, Battey H. The effects of low temperatures on the vegetative growth and flowering of the primocane fruiting raspberry 'Autumn Bliss'. Journal of Horticultural Science \& Biotechnology. 2001;76:264-70.

[14] Chouard P. Vernalization and its relation to dormancy. Annual Review of Plant Physiology. 1960;11:191-237.

[15] Koskela E, Kurokura T, Toivainen T, Sønsteby A, Heide O, Sargent D, Isobe S, Jaakola L, Hilmarsson H, Elomaa P, Hytönen T. Altered regulation of TERMINAL FLOWER1 causes the unique vernalisation response in an artic woodland strawberry accession. New Phytologist. 2017;216:841-53.

[16] Rantanen M, Kurokura T, Jiang P, Mouhu K, Hytönen T. Strawberry homologue of TERMINAL FLOWER1 integrates photoperiod and temperature signals to inhibit flowering. The Plant Journal. 2015;82:163-73.

[17] Blázquez M, Weigel D. Integration of floral inductive signals in Arabidopsis. Nature. 2000;404:889-92.

[18] Tofiño A, Romero M, Cabal D. 2013. Aspectos moleculares de la Inducción y el desarrollo floral. Disponible en www.corpoica.org.co/sitioweb/ofertas/articulo.asp?id=1356.

[19] Vincent-Prue D, Fosket D, Amasino R. The control of flowering. In: Taiz, L. Zeiger, E. Eds. Plant physiology. Quinta edición. Sinauer Associates Inc. U.S.A. 2010;719-53.

[20] Bewley J, Hempel F, McCormick S, Zambryski P. Reproductive development. In: Buchanan, B. Gruissem, W. Jones, R. Eds. Biochemistry \& Molecular Biology of Plants. American Society of Plant Physiologists. U.S.A. 2000;988-1006.

[21] Horvath D. Common mechanisms regulate flowering and dormancy. Plant Science. 2009;177:523-31.

[22] Koskela E, Mouhu K, Albani M, Kurokura T, Rantanen M, Sargent D, Battey N, Coupland G, Elomaa P, Hytönen T. Mutation in TERMINAL FLOWER1 reverses the photoperiodic requirement for flowering in the wild strawberry Fragaria vesca. Plant Physiology. 2012;159:1043-54.

[23] Iwata H, Gaston A, Remay A, Thouroude T, Jeauffre J, Kawamura K, Hibrand-Saint L, Araki T, Denoyes B, Foucher F. The TFL1 homologue KSN is a regulator of continuous flowering in rose and strawberry. The Plant Journal. 2012;69:116-25.

[24] Kurokura T, Mimida N, Battey N, Hytönen T. The regulation of seasonal flowering in the Rosaceae. Journal of experimental botany. 2013;64(14):4131-41.

[25] Neri D, Massetani F, Zucchi P, Giacomelli M, Savini G. Flower differentiation and plant architecture of Raspberry, Blackberry and Currant. Acta Horticulturae. 28th International Horticultural Congress. 2012;926:243-50.

[26] Yu D, Tang H, Zhang Y, Du Z, Yu H, Chen Q. Comparison and improvement of different methods of RNA isolation from strawberry (Fragaria X ananassa). Journal of Agricultural Science. 2012;4(6):51-56.98.

[27] Pfaffl M. A new mathematical model for relative quantification in real-time RT-PCR. Nucleic Acids Research. 2001;29(9):2002-7.

[28] Thomas CR, Maurice SC. Statistix 9, in Managerial Economics, 9th edition, McGraw-Hill/Irwin. 2009.

[29] López-Medina J, Moore J. Chilling enhances cane elongation and flowering in primocane-fruiting blackberries. Hortscience. 1999;34:638-40. 
[30] Takeda F. Chilling effects flowering of primocane fruiting 'Heritage' raspberry. Acta Horticulturae. 1993;352:247-52.

[31] Vasilakakis M, McCown B, Dana M. Low temperature and flowering of primocane-fruiting red raspberry. HortScience. 1980;15:750-1.

[32] Williams H. Effects of environment on Rubus idaeus L.V. Dormancy and flowering of the mature shoot. Journal of Horticultural Science. 1960;35:214-20.

[33] Sønsteby A, Heide O. Earliness and fruit yield and quality of annual-fruiting red raspberry (Rubus idaeus L.): Effects of temperature and genotype. Journal of Horticultural Sciencie \& Biotechnology. 2010;85:341-9.

[34] Carew J, Mahmood K, Darby J, Hadley P, Battey H. The effect of temperature, photosynthetic photon flux density, and photoperiod on the vegetative growth and flowering of 'Autumn Bliss' raspberry. Journal Amer Soc Hort Sci. 2003;128(3):291-6.

[35] Tanino K, Kalcsits L, Silim S, Kendall E, Gray G. Temperature-driven plasticity in growth cessation and dormancy development in deciduous woody plants: A working hypothesis suggesting how molecular and cellular function is affected by temperature during dormancy induction. Plant Molecular Biology. 2010;73:49-65. 